Jurnal Akuntansi \& Manajemen Akmenika Vol. 16 No. 2 Tahun 2019

\title{
PENGARUH PLANNING TAX, DAN DEBT TO EQUITY RATIO (DER) DAN KEPEMILIKAN MANAJERIAL TERHADAP NILAI PERUSAHAAN PADA INDUSTRI PERTAMBANGAN YANG TERDAFTAR PADA BURSA EFEK INDONESIA PERIODE 2014-2018
}

\author{
Hari Purnama \\ Fakultas Bisnis, Universitas PGRI Yogyakarta \\ Email: haripurnama22@gmail.com
}

\begin{abstract}
ABSTRAK
Penelitian ini bertujuan untuk menguji pengaruh Perencanaan Pajak, Debt to Equity Ratio (DER), dan Kepemilikan Manajerial secara parsial terhadap Nilai Perusahaan dan untuk menguji pengaruh Perencanaan Pajak, Debt to Equity Ratio (DER), dan Kepemilikan Manajerial secara simultan terhadap Nilai Perusahaan. Variabel penelitian ini terdiri dari variabel bebas dan terikat. Variabel bebas penelitian ini adalah Tax Planning, Debt to Equity Ratio (DER), dan Kepemilikan Manajerial, sedangkan variabel terikatnya adalah Nilai Perusahaan. Populasi dalam penelitian ini yaitu seluruh perusahaan Pertambangan yang terdaftar di Bursa Efek Indonesia Periode 2014-2018. Teknik Pengambilan Sampel purposive sampling. Metode pengambilan data menggunakan kepustakaan dan dokumentasi. Teknik analisis yang digunakan adalah regresi linier berganda dengan taraf signifikansi $5 \%$.

Perencanaan pajak tidak berpengaruh terhadap Nilai Perusahaan Pertambangan yang terdaftar di Bursa Efek Indonesia Periode 2014-2018. Debt to Equity Ratio (DER) berpengaruh positif terhadap nilai perusahaan Pertambangan yang terdaftar di Bursa Efek Indonesia Periode 2014-2018. Kepemilikan manajerial berpengaruh positif terhadap Nilai Perusahaan Pertambangan yang terdaftar di Bursa Efek Indonesia Periode 2014-2018. Perencanaan Pajak, Debt to Equity Ratio (DER), dan Kepemilikan Manajerial secara simultan berpengaruh positif dan signifikan terhadap Nilai Perusahaan.
\end{abstract}

Kata Kunci : Perencanaan Pajak, Debt to Equity Ratio (DER), kepemilikan Manajerial dan Nilai perusahaan

\begin{abstract}
The purpose of this study was to determine the effect of Tax Planning, Debt to Equity Ratio (DER), and Managerial ownership partially positive and significant effect on firm value. to determine the effect of Tax Planning, Debt to Equity Ratio (DER), and Managerial ownership simultaneously have a positive and significant effect on firm value.

The variables of this study are Tax Planning, Debt to Equity Ratio (DER), Managerial Ownership, and Firm Value. The population in this study are all mining companies listed on the Indonesia Stock Exchange in the 2014-2018 period. Purposive Sampling Technique. The method
\end{abstract}


of collecting data uses literature and documentation. The analysis technique used is multiple linear regression with a significance level of 5\%.

Tax planning has no effect on the value of Mining Companies listed on the Indonesia Stock Exchange in the 2014-2018 period. Debt to Equity Ratio (DER) has a positive effect on the value of Mining companies listed on the Indonesia Stock Exchange in the 2014-2018 Period. Managerial ownership has a positive effect on the value of Mining Companies listed on the Indonesia Stock Exchange in the 2014-2018 Period. Tax Planning, Debt to Equity Ratio (DER), and Managerial ownership simultaneously have a positive and significant effect on company value.

\section{Keywords: Tax Planning, Debt to Equity Ratio (DER), Managerial ownership and Firm value}

\section{PENDAHULUAN}

Nilai perusahaan merupakan salah satu komponen indikator keberhasilan perusahaan, dengan nilai perusahaan yang tinggi menunjukkan keberhasilan mencapai tujuan perusahaan. Nilai perusahaan dapat dilihat dari harga pasar saham perusahaan. Indikator peningkatan nilai perusahaan menunjukkan kesejahteraan pemegang saham juga meningkat. Peningkatan nilai perusahaan diatndai dengan peningkatan return saham tiap periode. Return saham yang meningkatkan membuktikan bahwa tingkat pengembalian dana invstor semakin cepat. Hal ini akan menarik investor lain untuk menanmkan modalnya dalam perusahaan tersebut. Peningkatan kesejahteraan pemegang saham yang dinindikatorkan dnegan peningkatan return saham tersebut dapat meningkatkan ketertairikan investor lain untuk menanmkan modalnya, dimana hal tersebut akan memicu kenaikkan harga saham di pasar perusahaan tersebut, sehingga nilai harga saham yang meningkat akan meningkatkan nilai perusahaan.

Keberhasilan perusahaan dalam mencapai tujuan tidak terlepas dari peran dari pihak-pihak yang berkepentingan dan merasakan dampak dari kondisi perusahaan yaitu semua stakeholder dalam perusahaan. Pemilik perusahaan, manajer dan lainnya yang mempunyai kepentingaan dalam perusahaan, bersama-sama mengharapakn peningkat nilai perusahaan, sebab indikator dari peningkatkan kesejateraan stokholder perusahaan adalah nilai perusahaan yang terus meningkat. Selain menjadi tujuan perusahaan nilai perusahaan merupakan tujuan jangka panjang perusahaan tersebut. Pradnyana dan Noviari (2017). Menyatakan kepentingan pemilik perusahaan (stakeholders), termasuk pemegang saham, sering disalahgunakan oleh manajer. Jensen dan Meckling (1976) dalam Pradnyana dan Noviari (2017). Mendsekripsikan bahwa gap kepentingan antara pemilik perusahaan dalam hal ini pemegang saham dengan manajer sering terjadi pada suatu perusahaan yang berkembang, masalah yang sering terjadi adalah manajer bertindak seolah-olah demi kepentingan pemimlik perusahaan, tetapi kenyataanya manajer mementingkan kepentingganya dalam mengambl keptusan, sehingga keputusan keuangan dari manajemen tersebut dapat mempegaruhi nilai perusahaan. Salah satu kebijakan manajer yang dapat menurunkan nilai perusahaan adalah memenimalkan pembayaran pajaknya, atau yang disebut dengan perencanaan pajak.

Pajak merupakan salah satu faktor komponen pengurang laba bersih. Biaya pajak yang terlalu besar akan dapat mengurangi laba bersih perusahaan, sehingga amanajer berusahaan membayar pajak terutangnya seminimal mungkin (Qomariyah, 2018). Usaha manajemen perusahaan dalam membayar pajak terutangnya dengan melakukan manajemen pajak atau perencanaan pajak yang masih sesuai dengan koridor undang-undang 
perpajakan. Perbedaan sudat pandang antara perusahaan dengan pemerintah dalam hal besarnya pajak yang harus dibayar perusahaan mendorong manajemen perusahaan melakukan beberapa cara, salah satunya dengan melakukan manajemen pajak. Manajemen pajak adalah suatu cara dalam menunaikan kewajiban perpajakan yang sinkron dengan undang-undang yang berlaku, tetapi beban pajak terutang mampu diminimalisir seminimal mungkin guna mendapatkan keuntungan serta likuiditas yang diinginkan (Suandy, 2014). Sedangkan perencanana pajak merupakn salah satu dari manajemen pajak yang fokus melakukan minimalisasi pembayaran pajak terutang.

Perencanaan pajak adalah tahapan pertama dari manajemen pajak, dimana hal tersebut tidak dapat disipisahkan dari strategi perusahaan secara menyeluruh (Hanlon dan Heitzman, 2013). Berdasarkan pendapat tersebut, maka perencanaan pajak dapat menentukan strategi kebijakan perusahaan secara meyeluruh dan merupakan salah satu indikator dari keberhasilan perusahaan. Semakin sukses perencenaan pajak dan tidak melanggar ataruan undang-undang yang berlaku, maka akan meningkatkan laba bersih perusahaan, yang pada akhirnya akan berdampak pada nilai perusahaan. Pengeloan pajak yang efektif, maka akan mampu mendorong kepercayaan investor menjadi meningkat, sehingga akan meningkatkan harga saham perusahaan. Naiknya harga saham akan meningkatkan nilai perusahaan (Pradnyana dan Noviari, 2017). Selain tax planning nilai perusahaan juga bisa dipengaruhi Debt to Equity Ratio (DER).

Faktor Debt to Equity Ratio (DER), berhubungan dengan kekuatan modal dalam perusahaan. Perusahaan yang memliki komposisi modal yang tepat, akan mampu mengelola modalnya dengan efektif, sehingga akan meningkatkan laba perusahaan. Peningkatan laba perusahaan, akan diikuti dengan meningkatnya harga saham perusahaan. Laba yang optimal akan menarik investor untuk menanamkan modalnya di perusahaan tersebut. Modal bagi perusahaan sangat dibutuhkan untuk dapat bersaing dengan perusahaan lainnya. Dengan modal yang kuat perusahaan dapat melakukan inovasi produk dan invansi pasar untuk dapat meperoleh konsumen sebanyakbanyaknya. Modal perusahaan dapat dipenuhi dari dua sisi yaitu ekuiatas dan modal pinjaman. Ekuitas dapat diperoleh lewat pasar modal. Pemilihan sumber dana perusahaan akan berpengaruh pada laba per lembar saham yang pada akhirnya akan berpengaruh pada nilai perusahaan. Semakin efektif perusahaan menggunakan sumber dana dari pinjaaman, maka meningkatkan laba perusahaan per lembar saham atau nilai perusahaan semakin meningkat. Tetapi dibalik itu sumber dana pinjaman memliki resiko tinggi yaitu beban bunga pada perusahaan. Sedangkan alternatif lain perusahaan menggunakan sumber dana dari ekuitasnya.

Perusahaan dalam rangka memaksimalkan labanya harus mampu menacari alternatif sumber dana yang menguntungkan. Untuk memperoleh ekuitas tambahan tidak mudah, perusahaan perlu mempertimbangkan risiko yang akan terjadi. Disinilah perusahaan perlu mengambil kebijakan liabilitas perusahaan dengan tujuan mendongkrak kinerja perusahaan. Untuk itu diperlukan rasio khusus untuk melibatkan kinerja tersebut, yaitu Debt to Equity Ratio (DER). DER merupakan rasio untuk membandingkan jumlah liabilitas terhadap ekuitas. Perusahaan yang mempunyai rasio DER yang tinggi tidak baik bagi perusahaan. Tingkat pendanaan yang disediakan pemilik atau perusahaan harus maksimal. Semakin besar batas pengamanan bagi pinjaman maka akan terjadi kerugian atau penyusutan terhadap nilai aset. Debt to Equity Ratio (DER) merupakan rasio yang digunakan untuk menilai liabilitas dengan ekuitas. Rasio ini dicari dengan cara membandingkan antara 
seluruh liabilitas, termasuk liabilitas lancar dengan seluruh ekuitas (Kasmir, 2016)

Selain Debt to Equity Ratio (DER), yang tidak kalah pentingnya adalah peran manajemen, dalam hal ini manajer perusahaan sering mengambil keputusan yang berseberangan dengan kepentingan pemilik perusahaan. Untuk mengatasi hal tersebut maka manajer perlu memliki sebagain saham dari perusahaan, supaya keputusanya dapat mengendalikan perusahaan sesuai tujuan perusahaan yaitu meningkatkan kesejahteraan stakholder perusahaan. Struktur kepemilikian saham manajerial akan berdampak pada bagaimana manajemen melakukan investasi sesuai harapan pemilik perusahaan. Komposisi saham manajerial dengan jumlah saham beredar disebut struktur kepemilikan manajerial. Saham yang dikuasai manajer dibandingkan dengan seluruh saham beredar adalah kepemilikan manajerial. Semakin besar kepemilikan manajerial, maka manajemen akan berusaha secara optimal dalam meningkatkan nilai perusahaan. Hal ini karena dengan komposisi kepemilikan saham yang lebih besar maka manajemen memiliki kepentingan harapan return saham yang besar, untuk itu faktor keterlibatan manajemen dalam kepemilikan saham akan berpengaruh pada perkembangan perusahaan secara menyeluruh, termasuk nilai perusahaan.

\section{KAJIAN TEORI DAN PENGEMBANGAN HIPOTESIS}

\section{Nilai Perusahaan}

Nilai perusahaan adalah nilai pasar saham suatu perusahaan yang dapat memebrikan kemakmuran pemegang saham secara optimal. Nilai perusahaan dapat diindikatorkan pada peningkatan harga saham atau besarnya return saham. Pada penelitian ini nilai perusahaan diukur dengan Price Book Value (PBV). Menurut Brigham dan Houston (2011), Nilai perusahaan dapat diformulasikan sebagai berikut:

$$
\mathrm{PBV}=\frac{\text { Harga Saham }}{\mathrm{BV}}
$$

\section{Perencanaan Pajak (Tax Planning)}

Perencanaan pajak adalah usaha wajib pajak badan atau perusahaan untuk meminimalkan pajak terhutang dengan metode yang dibenarkan undang-undang perpajakan yang berlaku (Hanlon dan Heitzman, 2013). Perencanaan pajak dapat diukur dengan formula effektive tak rate. Menurut Hanlon dan Heitzman, (2013) effective tax rate (ETR) dapat dihitung dengan rumus:

$$
\text { ETR }=\frac{\text { Beban Pajak (Kas yang dikeluarkan untuk membayar pajak) }}{\text { Laba Sebelum Pajak }}
$$




\section{Debt to Equity Ratio (DER)}

Debt to Equity Ratio (DER) adalah komposisi antara total hutang dengan modal sendiri. Rasio ini digunakan untuk mengukur seberapa besar perusahaan dibiayai oleh hutang dengan modal sedniri. Menurut Kasmir (2016), Debt to Equity Ratio (DER) dapat dirumuskan sebagai berikut:

$$
\text { DER }=\frac{\text { Total Hutang }}{\text { Total Modal Sendiri }}
$$

\section{Kepemilikan Manajerial}

Kepemilikan manajeraial adalah komposisi antara jumlah saham yang dimiliki manajerial dengan jumlah saham yang beredar di publik (Jahera dan Aurburn, 1996). Adapun kepemilkan manajerial dapat diformulasikan sebagai berikut:

$$
\mathrm{KM}=\frac{\text { Total Saham Manajerial }}{\text { Total Saham Beredar }}
$$

\section{Pengaruh Perencanaan Pajak Terhadap Nilai perusahaan}

Perencanaan pajak dilakukan untuk memenimalkan total pajak yang akan dibayar wajib pajak secara legal sesuai aturan perpajakan yang berlaku. Perencanaan pajak merupakan tindakan yang legal dikarenakan penghematan pajak hanya diterapkan dari hal-hal yang dalam undang-undang tidak dicantumkan (Suandy, 2014). Perencanaan pajak adalah tahapan pertama dari manajemen pajak, dimana hal tersebut tidak dapat disipisahkan dari strategi perusahaan secara menyeluruh (Hanlon dan Heitzman, 2013). Berdasarkan pendapat tersebut, maka perencanaan pajak dapat menentukan strategi kebijakan perusahaan secara meyeluruh dan merupakan salah satu indikator dari keberhasilan perusahaan. Semakin sukses perencenaan pajak dan tidak melanggar ataruan undang-undang yang berlaku, maka akan meningkatkan laba bersih perusahaan, yang pada akhirnya akan berdampak pada nilai perusahaan. Pengeloan pajak yang efektif, maka akan mampu mendorong kepercayaan investor menjadi meningkat, sehingga akan meningkatkan harga saham perusahaan. Naiknya harga saham akan meningkatkan nilai perusahaan (Pradnyana dan Noviari, 2017).
Peneliti terdahulu Pradnyana dan Noviari (2017), perencanaan pajak memliki pengaruh signifikan terhadap Nilai Perusahaan. Penghematan pajak perusahaan mampu berpengaruh terhadap laba perusahaan yang pada akhirnya akan berpengaruh pada nilai perusahaan. Peneliti lain Wulandari (2016), efek perencanaan pajak tidak berpengaruh terhadap nilai perusahaan. Perusahaan yang mampu merencanakan pajaknya dengan efektif, maka keuntungan tidak hanya dari sudut fiskal saja tetapi perusahaan juga akan memperoleh suntikan modal dari pihak investor melalui penjualan saham. Saham yang semakin meningkat harganya akarena permintaan akan meningkatkan return saham, sehingga akan meningkatkan nilai perusahaan. Pajak yang merupakan unsur pengurang laba yang dapat dibagikan sebagai dividen kepada investor. Sehingga apabila perencanaan pajak berjalan secara efektif maka akan mampu meningkatkan Nilai perusahaan. (Pradnyana dan Noviari, 2017). Berdasarkan uraian tersebut, maka hipotesis penelitian ini adalah:

$\mathrm{H}_{1}=$ Perencanaan Pajak berpengaruh positif dan signifikan Terhadap Nilai perusahaan 
Pengaruh Debt to Equity Ratio (DER) Terhadap Nilai perusahaan

Perusahaan dalam rangka memaksimalkan labanya harus mampu menacari alternatif sumber dana yang menguntungkan. Untuk memperoleh ekuitas tambahan tidak mudah, perusahaan perlu mempertimbangkan risiko yang akan terjadi. Disinilah perusahaan perlu mengambil kebijakan liabilitas perusahaan dengan tujuan mendongkrak kinerja perusahaan. Untuk itu diperlukan rasio khusus untuk melibatkan kinerja tersebut, yaitu Debt to Equity Ratio (DER). DER merupakan rasio untuk membandingkan jumlah liabilitas terhadap ekuitas. Perusahaan yang mempunyai rasio DER yang tinggi tidak baik bagi perusahaan. Tingkat pendanaan yang disediakan pemilik atau perusahaan harus maksimal. Semakin besar batas pengamanan bagi pinjaman maka akan terjadi kerugian atau penyusutan terhadap nilai aset. Debt to Equity Ratio (DER) merupakan rasio yang digunakan untuk menilai liabilitas dengan ekuitas. Rasio ini dicari dengan cara membandingkan antara seluruh liabilitas, termasuk liabilitas lancar dengan seluruh ekuitas (Kasmir, 2016)

Peneliti Ichsan (2016), menyatakan DER berpengaruh positif dan signifikan terhadap Nilai perusahaan. Peneliti Mudjijah (2015), berbeda DER berpengaruh negatif dan tidak seigniifikan terhadap Nilai perusahaan. Pengaruh Debt to Equity Ratio (DER) terhadap nilai perusahaan secara positif apabila perusahaan dapat mengelola hutangy dengan efektif, sehingga kepercayaan investor meningkat dalam menanamkan modalnya yang berdampak pada meningkatnya nilai perusahaan.

Berdasarkan keterangan diatas Debt to Equity Ratio (DER) memeili resiko tinggi berupa beban bunga hutang. Untuk itu perusahaan yang tidak dapat mengelola hutang dengan biak cederung menggunakan modal sendiri. Sehingga dapat disimpulkan Debt to Equity Ratio (DER) tinggi maka Nilai perusahaan menjadi tinggi sehingga menguntungkan bagi perusahaan. Berdasarkan uraian tersebut, maka hipotesis penelitian ini adalah:

$$
\begin{aligned}
\mathrm{H}_{2}= & \text { Debt to Equity Ratio (DER) } \\
& \text { berpengaruh positif dan signifikan } \\
& \text { Terhadap Nilai perusahaan }
\end{aligned}
$$

\section{Pengaruh Kepemilikan Manajerial Terhadap Nilai perusahaan}

Struktur kepemilikian saham manajerial akan berdampak pada bagaimana manajemen melakukan investasi sesuai harapan pemilik perusahaan. Komposisi saham manajerial dengan jumlah saham beredar disebut struktur kepemilikan manajerial. Saham yang dikuasai manajer dibandingkan dengan seluruh saham beredar adalah kepemilikan manajerial. Semakin besar kepemilikan manajerial, maka manajemen akan berusaha secara optimal dalam meningkatkan nilai perusahaan. Hal ini karena dengan komposisi kepemilikan saham yang lebih besar maka manajemen memiliki kepentingan harapan return saham yang besar, untuk itu faktor keterlibatan manajemen dalam kepemilikan saham akan berpengaruh pada perkembangan perusahaan secara menyeluruh, termasuk nilai perusahaan.

Peningkatan kepemilikan manajerial dapat berfungsi sebagai penghubungan antara pihak internal dengan pemegang saham atau pemilik perusahaan, hal ini akan mendorong manajemen mengambil keputusan lebih baik, sehingga akan meningatkan kepercayaan investor, kemudian akan meningkatkan harga saham, yang merupakan salah satu indikator dari kenaikan nilai perusahaan (Wida dan Suartana, 2014). Peneliti Wida dan Suartana, (2014), menyatakan bahwa kepemilikan manajerial belum mammpu berpenagruh secara signifikan terhadap nilai perusahaan. Sedangkan Budianto dan Payamta (2014), menyatakan bahwa kepemilikan manajerial berpengaruh negatif terhadap nilai perusahaan. Berdasarkan 
uraian tersebut, maka hipotesis penelitian ini adalah:

$\mathrm{H}_{3}=$ Kepemilikan Manajerial berpengaruh positif dan signifikan Terhadap Nilai perusahaan

Pengaruh Perencanaan Pajak, Debt to Equity Ratio (DER) dan Kepemilikan Manajerial, terhadap Nilai perusahaan

Nilai perusahaan merupakan salah satu komponen indikator keberhasilan perusahaan, dengan nilai perusahaan yang tinggi menunjukkan keberhasilan mencapai tujuan perusahaan. Nilai perusahaan dapat dilihat dari harga pasar saham perusahaan. Indikator peningkatan nilai perusahaan menunjukkan kesejahteraan pemegang saham juga meningkat. Peningkatan nilai perusahaan diatndai dengan peningkatan return saham tiap periode. Return saham yang meningkatkan membuktikan bahwa tingkat pengembalian dana invstor semakin cepat. Hal ini akan menarik investor lain untuk menanmkan modalnya dalam perusahaan tersebut. Peningkatan kesejahteraan pemegang saham yang dinindikatorkan dnegan peningkatan return saham tersebut dapat meningkatkan ketertairikan investor lain untuk menanmkan modalnya, dimana hal tersebut akan memicu kenaikkan harga saham di pasar perusahaan tersebut, sehingga nilai harga saham yang meningkat akan meningkatkan nilai perusahaan (Sartono, 2010).
Memaksimumkan nilai perusahaan disebut sebagai memaksimumkan kemakmuran para pemegang saham yang akan diterima apabila aset perusahaan dijual sesuai dengan harga saham (Martono dan harjito, 2010). Nilai pemegang saham akan meningkat apabila nilai perusahaan juga meningkat yang ditandai dengan tingkat pengembalian investasi yang tinggi kepada pemegang saham (Husnan, 2000).

Perusahaan melakukan perencanaan pajak seefektif mungkin untuk dapat diminimalkan biaya pajak dan mengoptimalkan nilai perusahaan. Begitu pula DER yang tinggi, menunjukkan tingkat kepercayaan investor tinggi pula, sehingga akan meniningkatkan Nilai perusahaan. Kemudian suatu perusahaan juga menambah jumlah Saldo Laba yang bertujuan agar kegiatan operasional perusahaan berjalan lancar dan akan memperkuat posisi keuangan perusahaan. Selain itu juga untuk membiayai aktivitas perusahaan yang semakin meningkat, perusahaan harus memperoleh pendapatan yang maksimal dan meningkatkan laba perusahaan sehingga akan meningkatkan Nilai perusahaan. Berdasarkan uraian tersebut, maka hipotesis penelitian ini adalah:

$\mathrm{H}_{4}=$ Pengaruh Perencanaan Pajak, Debt to Equity Ratio (DER), dan kepemilikan Manajerial secara simultan berpengaruh positif dan signifikan terhadap Nilai perusahaan 


\section{Kerangka Berpikir}

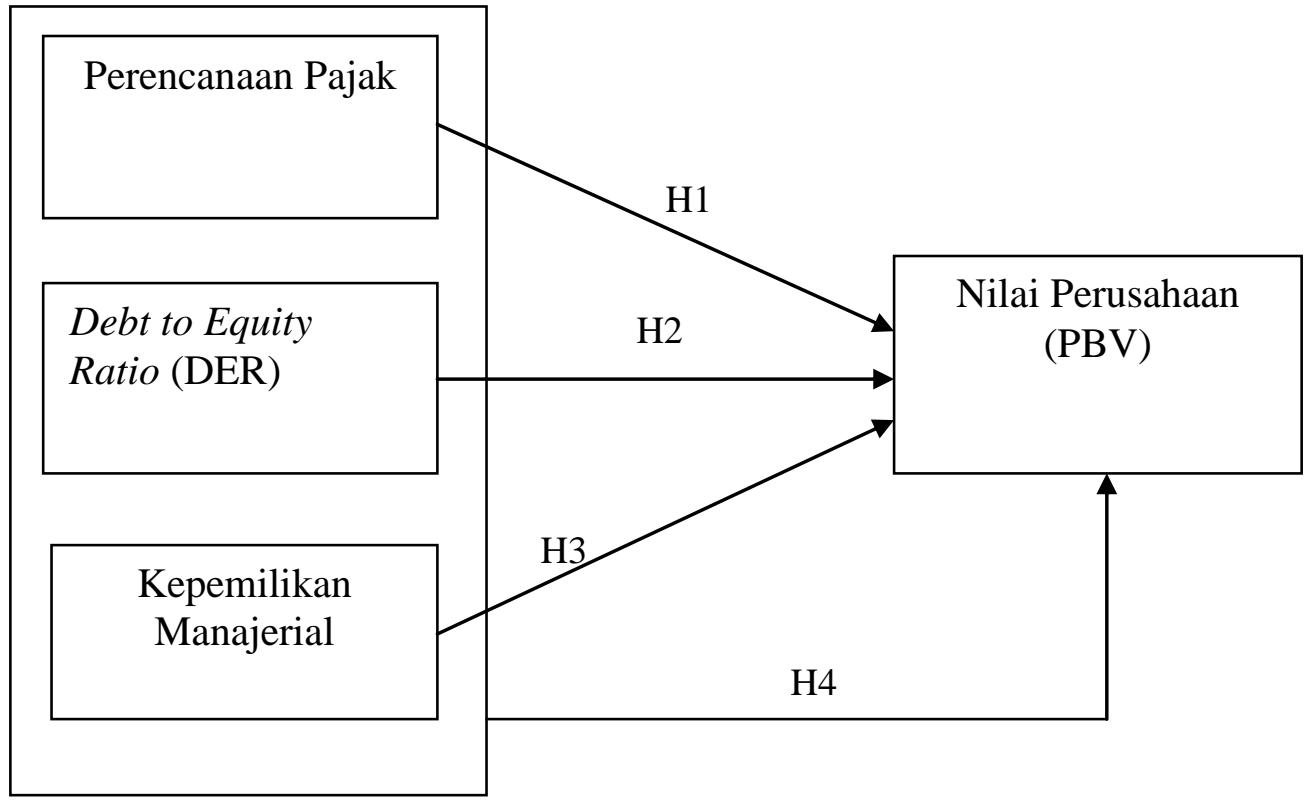

Gambar 1

Kerangka Berpikir

\section{METODOLOGI PENELITIAN Sifat Penelitian}

Penelitian ini bersifat korelasional yaitu jenis penelitian yang fokus pada analisis hubungan sebab akibat dua variabel yang diteliti. Peneliti mencoba untuk mengetahui sejauh mana tingkat hubungan kedua variabel.

\section{Variabel Penelitian}

Variabel penelitian ini adalah Tax Planning, Debt to Equity Ratio (DER), Kepemilikan Manajerial, dan Nilai perusahaan.

Populasi adalah keseluruhan obyek penelitian baik terdiri dari benda yang nyata, abstrak, peristiwa ataupun gejala yang merupakan sumber data dan memiliki karakter tertentu dan sama (Sugiyono,
2016). Populasi dalam penelitian ini yaitu seluruh perusahaan Pertambangan yang terdaftar di Bursa Efek Indonesia Periode 2014-2018.. Sampel adalah bagian dari populasi yang memiliki sifat-sifat yang sama dari obyek yang merupakan sumber data (Sugiyono, 2016). Teknik Pengambilan Sampel purposive sampling.

\section{Teknik Analisa Data}

Teknik analisis data yang digunakann adalah menggunakan SPSS 20.0. Langkah yang digunakan untuk menganalisis data yaitu dengan statistic deskriptif, uji asumsi klasik (uji multikoliniearitas, uji heterokesdastisitas, uji normalitas), analisis regresi berganda dan uji hipotesis. 


\section{HASIL DAN PEMBAHASAN}

Uji Asumsi Klasik

Uji Normalitas

Tabel 1. Hasil Uji Normalitas

\begin{tabular}{|c|c|}
\hline & Unstandardized Residual \\
\hline Kolmogorov Smirno Z & 0,649 \\
\hline Assymp. Sig & 0,794 \\
\hline
\end{tabular}

Hasil olah data diketahui nilai Kolmogrov-Smirnov $Z$ sebesar 0,649 dan nilai Asymp. Sig. (2tailed) sebesar 0,794, hal ini menunjukkan nilai signifikan lebih besar 0,05 (0,794>0,05), sehingga dapat disimpulkan bahwa data berdistribusi normal. Sedangkan dilihat secara grafik dapat dilihat pada gambar berikut:

Normal P-P Plot of Regression Standardized Residual

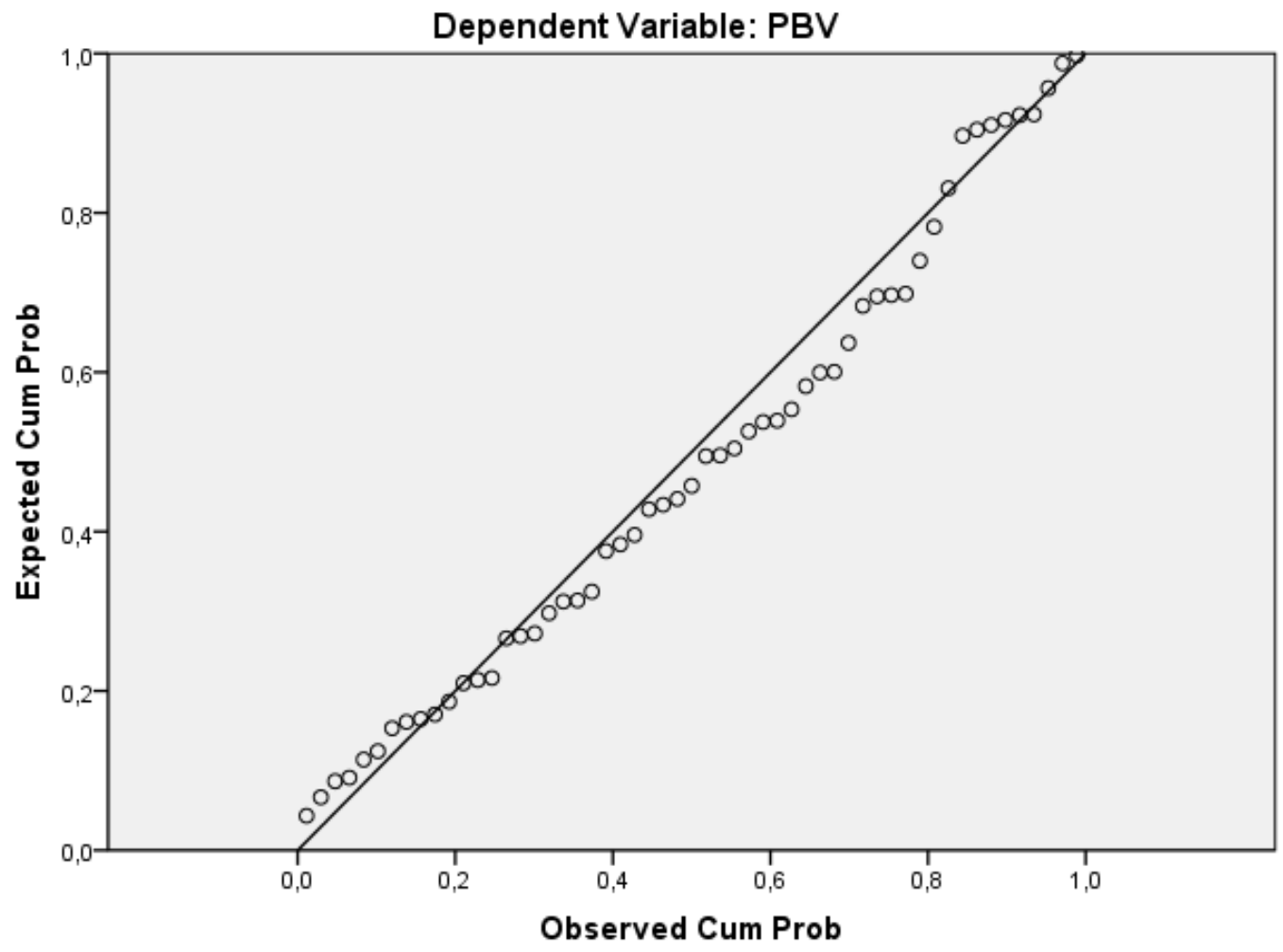

Gambar 1. Normal ProbabilityPlot

Berdasarkan output Gambar 1 dapat dilihat penyebaran pada data (titik-titik) menyebar disekitar sumbu diagonal, meskipun begitu penyebarannya tidak terlalu jauh dari garis diagonal. Hal ini menunjukan bahwa grafik memiliki pola distribusi normal, maka model regresi memenuhi normalitas. 


\section{Uji Multikolinearitas}

Tabel 2. Hasil Uji Multikolinieritas

\begin{tabular}{|ll|r|r|}
\hline \multirow{2}{*}{ Model } & \multicolumn{2}{|c|}{ Collinearity Statistics } \\
\cline { 2 - 3 } & Tolerance & \multicolumn{1}{c|}{ VIF } \\
\hline 1 (Constant) &, 970 & 1,031 \\
ETR &, 909 & 1,100 \\
DER &, 883 & 1,133 \\
Kep_Manaje &
\end{tabular}

a. Dependent Variable: PBV

Sumber: Data sekunder diolah, 2019.

Hasil olah data di atas menunjukkan tidak terjadi masalah multikolinieritas, hal ini ditunukkan dengan nilai tolerensi masing-masing variabel bebas lebih besar 0,10 dan nilai VIF lebih kecil 10.

\section{Uji Heterokedastisitas}

Tabel 3. Hasil Uji Heterokedastisitas

\begin{tabular}{|c|c|c|c|c|c|}
\hline \multirow[t]{2}{*}{ Model } & \multicolumn{2}{|c|}{$\begin{array}{l}\text { Unstandardized } \\
\text { Coefficients }\end{array}$} & \multirow{2}{*}{$\begin{array}{c}\text { Standardize } \\
\mathrm{d} \\
\text { Coefficient } \\
\mathrm{s}\end{array}$} & \multirow[b]{2}{*}{$\mathrm{t}$} & \multirow[b]{2}{*}{ Sig. } \\
\hline & $\mathrm{B}$ & Std. Error & & & \\
\hline 1 (Constant) &, 759 &, 292 & & 2,598 &, 012 \\
\hline ETR &,- 007 & ,468 &,- 002 &,- 015 & ,988 \\
\hline DER &,- 006 & 102 &,- 008 &,- 056 & ,956 \\
\hline $\begin{array}{l}\text { Kep_Manaj } \\
\text { e }\end{array}$ &, 090 & ,892 & 015 &, 101 & ,920 \\
\hline
\end{tabular}

a. Dependent Variable: Abs_Residual

Sumber: Data sekunder diolah, 2019.

Berdasarkan perhitungan olah data diketahui dari masing-masing variabe bebas memliki nilai signifikan lebih besar $(0,05)$. Artinta tidak terjadi gejala Heteroskesdatisiatas. Sedangkan berdasarkan hasil olah data dapat dilihat uji grafik heteroskedastisitas sebagai berikut:

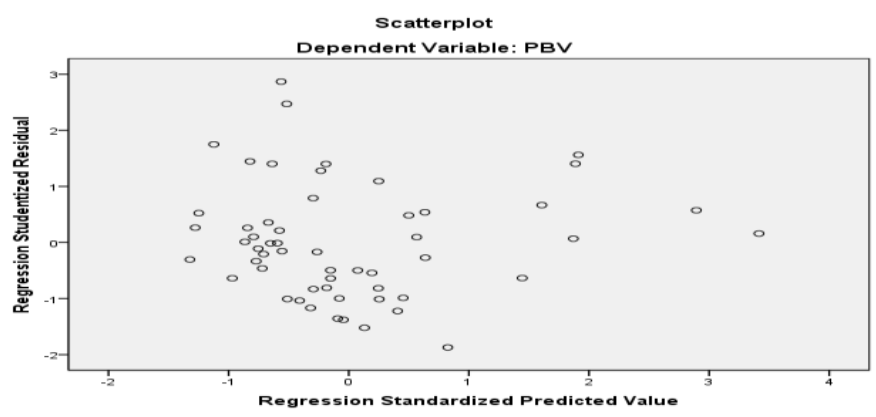

Gambar 2. Grafik Uji Heteroskedastisitas 
Grafik diatas menunjukkan bahwa data sudah menyebar dan tidak memebantuk pola, sehingga dapat disimpulkan tidak terjadi Heteroskesdatisitas.

\section{Uji Autokorelasi}

\section{Tabel 4. Hasil Uji Autokorelasi}

\begin{tabular}{|r|}
\hline Durbin Watson \\
\hline 1,951 \\
\hline
\end{tabular}

Hasil olah data menunjukkan nilai Durbin Watson (DW) sebesar 1,951. Hasil ini menunjukkan bahwa nilai DW berada diantara du dengan du - 4 (dw 1,951 berada diantara du dan 4-du, dari jumlah data (n) sebesar 55 variabel $\mathrm{k}=3$ maka diketahui $\mathrm{dl}=1,3384$ dan du sebesar 1,6589. Hasil ini dapat dismpulkan bahwa data tidak terjadi Autokorelasi.

\section{Analisa Regresi}

Setelah dilakukan pengujian uji asumsi klasik, maka langkah berikutnya memformulasikan persamaan regresi. Hasil analisis regresi digunakan dengan tujuan untuk memprediksi seberapa besar penagruh perencaaan pajak, DER dan Kepemilikan Manajerial terhadap nilai perusahaan. Hasil uji regresi dapat dilihat pada tabel berikut ini:

Tabel 5. Hasil Uji Analisis Regresi Berganda

\begin{tabular}{|l|r|r|r|r|r|}
\hline \multirow{2}{*}{ Model } & \multicolumn{2}{|c|}{$\begin{array}{c}\text { Unstandardized } \\
\text { Coefficients }\end{array}$} & $\begin{array}{c}\text { Standardized } \\
\text { Coefficients }\end{array}$ & \\
\cline { 2 - 4 } & \multicolumn{1}{|c|}{$\mathrm{B}$} & Std. Error & \multicolumn{1}{c|}{ Beta } & \multicolumn{1}{c|}{ Sig. } \\
\hline 1 (Constant) &,- 789 &, 472 & & $-1,672$ &, 101 \\
ETR &,- 129 &, 756 &,- 019 &,- 171 &, 865 \\
DER &, 417 &, 165 &, 287 & 2,523 &, 015 \\
Kep_Manaje & 6,108 & 1,441 &, 488 & 4,238 &, 000 \\
\hline
\end{tabular}

a. Dependent Variable: PBV

a. Persamaan

$Y=-0,789-0,129 X 1+0,417 X 2+6,108 X 3$

Dari persamaan regresi linear berganda diatas dapat dijelaskan sebagai berikut:

$\mathrm{b}_{0}=\mathbf{- 0 , 7 8 9}$ artinya jika nilai Perencanaan Pajak, Debt Equity Ratio (DER) sama dengan nol (0), maka nilai perusahaan nilainya sebesar $-0,789$.

$\mathrm{b}_{1}=-0,129$ artinya jika Perencanaan pajak mengalami kenaikan sebesar satu satuan maka Nilai perusahaan turun sebesar 0,129 satuan dengan asumsi variabel lain konstan.

$\mathrm{b}_{2}=0,417$ artinya jika Debt Quity Ratio (DER) mengalami kenaikan sebesar satu satuan maka nilai perusahaan meningkat sebesar 0,417 satuan dengan asumsi variabel lain konstan.

$b_{3}=6,108$ artinya jika Kepemilikan Manajerial mengalami kenaikan sebesar satu satuan maka nilai perusahaan meningkat sebesar 6,108 satuan dengan asumsi variabel lain konstan. 
b. Uji Koefisien Determinasi $\left(\mathbf{R}^{2}\right)$

Tabel 6. Hasil Uji Koefisien determinasi $\left(\mathbf{R}^{2}\right)$

Model Summary ${ }^{b}$

\begin{tabular}{|c|c|r|r|r|r|}
\hline Model & $\mathrm{R}$ & $\mathrm{R}$ Square & $\begin{array}{c}\text { Adjusted R } \\
\text { Square }\end{array}$ & $\begin{array}{c}\text { Std. Error of the } \\
\text { Estimate }\end{array}$ & $\begin{array}{c}\text { Durbin- } \\
\text { Watson }\end{array}$ \\
\hline 1 &, $634^{\mathrm{a}}$ &, 402 &, 367 & 1,030050 & 1,951 \\
\hline
\end{tabular}

a. Predictors: (Constant), Kep_Manaje, ETR, DER

b. Dependent Variable: PBV

Hasil olah data diatas menunjukkan bahwa nilai Adjusten R Square sebesar 0,367, artinya nilai perusahaan dipenagruhi perencanaan pajak, Debt Equity Ratio, dan kepemilikan manajerial sebesar $36,7 \%$, sisanya sebesar $63,3 \%$ dipengaruhi oleh variabel lain yang tidak diteliti dalam penelitian ini.

c. Uji Hipotesis

1) Uji Signifikan Simultan (Uji F)

Tabel 7. Hasil Uji Signifikan Simultan (Uji F) ANOVA $^{b}$

\begin{tabular}{|l|r|r|r|r|r|}
\hline Model & Sum of Squares & df & Mean Square & F & Sig. \\
\hline 1 Regression & 36,368 & 3 & 12,123 & 11,426 &, $000^{\mathrm{a}}$ \\
Residual & 54,111 & 51 & 1,061 & & \\
Total & 90,479 & 54 & & & \\
\hline
\end{tabular}

a. Predictors: (Constant), Kep_Manaje, ETR, DER

b. Dependent Variable: PBV

Tabel di atas menunjukkan hasil olah data uji F nilai signifikansi adalah 0,000. Artinya nilai signifikan lebih kecil $0,05(0,000<0,05)$ sehingga dapat disimpulkan bahwa Perencanaan Pajak, Debt Quity Ratio (DER) dan Kepemilikan Manajerial secara simultan berpengaruh terhadap Nilai Perusahaan.

\section{2) Uji Secara Parsial (Uji-t)}

Tabel 8. Hasil Uji Secara Parsial (Uji-t)

\begin{tabular}{|c|c|c|c|c|c|}
\hline \multirow[t]{2}{*}{ Model } & \multicolumn{2}{|c|}{ Unstandardized Coefficients } & $\begin{array}{c}\text { Standardized } \\
\text { Coefficients }\end{array}$ & \multirow[b]{2}{*}{$\mathrm{t}$} & \multirow[b]{2}{*}{ Sig. } \\
\hline & $\mathrm{B}$ & Std. Error & Beta & & \\
\hline 1 (Constant) &,- 789 &, 472 & & $-1,672$ &, 101 \\
\hline ETR &,- 129 & ,756 &,- 019 &,- 171 & ,865 \\
\hline DER & ,417 & ,165 & 287 & 2,523 & ,015 \\
\hline Kep_Manaje & 6,108 & 1,441 & ,488 & 4,238 & 000 \\
\hline
\end{tabular}

Berdasarkan tabel 8 dapat disimpulkan sebagai berikut:

Pengujian $\mathrm{H}_{1}$ : Perencanaan pajak berpengaruh positif terhadap Nilai Perusahaan Berdasarkan Tabel 8 Perencanaan pajak memiliki nilai beta -
0,129 dan bertanda negatif. Nilai signifikansinya sebesar 0,865 lebih besar dibandingkan dengan 0,05 , artinya tidak ada pengaruh antara variabel Perencanaan pajak terhadap Nilai Perusahaan. Berdasarkan hasil pengujian tersebut dapat dikatakan bahwa hipotesis 1 yang menyatakan Perencanaan pajak 
berpengaruh positif terhadap Nilai perusahaan tidak diterima.Pengujian $\mathbf{H}_{2}$ : Debt Quity Ratio (DER) berpengaruh positif terhadap Nilai Perusahaan. Berdasarkan Tabel 8. Debt Quity Ratio (DER) memiliki nilai beta 0,417 dan rtanda positif. Nilai signifikansinya sebesar 0,015 lebih kecil dari 0,05, artinya variabel Debt Quity Ratio (DER) berpengaruh positif dan signifikan terhadap Nilai Perusahaan Berdasarkan hasil pengujian tersebut dapat dikatakan bahwa hipotesis 2 yang menyatakan Debt Quity Ratio (DER) berpengaruh positif terhadap Nilai perusahaan diterima.

\section{Pengujian $\mathrm{H}_{3}$ : Kepemilikan Manajerial berpengaruh positif terhadap Nilai Perusahaan Berdasarkan Tabel 8.} Kepemilikan Manajerial memiliki nilai beta sebesar 6,108. Nilai signifikansinya sebesar 0,000 lebih kecil dari 0,05. Artinya variabel kepemilikan Manajerial berpengaruh positif dan signifikan terhadap Nilai Perusahaan. Berdasarkan hasil pengujian tersebut dapat dikatakan bahwa hipotesis 3 yang menyatakan Kepemilikan Manajerial berpengaruh positif terhadap Nilai perusahaan diterima.

\section{PEMBAHASAN}

\section{Pengaruh Perencanaan Pajak Terhadap Nilai perusahaan}

Dari hasil analisis yang telah dilakukan dapat diketahui bahwa variabel perencanaan pajak tidak berpengaruh terhadap Nilai Perusahaan Pertambangan yang terdaftar di Bursa Efek Indonesia Periode 2014-2018. Hal ini menunjukkan bahwa perencanaan pajak perusahaan Pertambangan belum optimal sehingga belum mampu mepenagruhi nilai perusahaan.

Hal ini tidak mendukung peneliti sebelumnya yang dilakukan Pradnyana dan Noviari (2017) yang menemukan bahwa perencanaan pajak berpengaruh signifikan terhadap nilai perusahaan.
Pengehematan pajak yang tidak sesuai dengan peraturan perundangan-undangan justru akan mengandung resiko besar yang akan menurunkan nilai peruahaan. Sedangkan perencanaan pajak yang dikelola sesui aturan yang berlaku mampu meningkatkan nilai perusahaan.

Hal ini sesuai pendapat Suandy, (2014) menyatakan bahwa usaha manajemen perusahaan dalam membayar pajak terutangnya dengan melakukan manajemen pajak atau perencanaan pajak yang masih sesuai dengan koridor undangundang perpajakan. Perbedaan sudat pandang antara perusahaan dengan pemerintah dalam hal besarnya pajak yang harus dibayar perusahaan mendorong manajemen perusahaan melakukan beberapa cara, salah satunya dengan melakukan manajemen pajak. Manajemen pajak adalah suatu cara dalam menunaikan kewajiban perpajakan yang sinkron dengan undang-undang yang berlaku, tetapi beban pajak terutang mampu diminimalisir seminimal mungkin guna mendapatkan keuntungan serta likuiditas yang diinginkan

\section{Pengaruh Debt to Equity Ratio (DER) Terhadap Nilai perusahaan}

Dari hasil analisis yang telah dilakukan dapat diketahui bahwa variabel Debt to Equity Ratio (DER) berpengaruh positif terhadap Nilai Perusahaan, Perusahaan Pertambangan yang terdaftar di Bursa Efek Indonesia Periode 20142018. Hasil ini menunjukkan semakin tinggi DER, maka nilai perusahaan akan semakin tinggi. Perusahaan Pertambangan karena untuk membiayai operasionalnya membutuhkan dana besar untuk itu salah satu pemenuhanya menggunakan hutang yang besar pula, tetapi dari hasil hutang tersebut dapat dkelola secara efektif sehingga menghasilkan laba yang tinggi, yang pada akhirnya akan meningkatkan harg saham dipasar, sehingga meningkatkan nilai perusahaan. 
Hal ini senada dengan penelitian yang dilakukan oleh Mudjijah (2015), berbeda Debt to Equity Ratio (DER) berpengaruh positif terhadap Nilai perusahaan. Pengaruh Debt to Equity Ratio (DER) terhadap EPS bersifat positif artinya, setiap kenaikkan Debt to Equity Ratio (DER), maka akan diikuti kenaikkan nilai perusahaan. Hal ini sesuai pendapat Kasmir, (2016) menyatakan bahwa Semakin besar Debt to Equity Ratio (DER) mencerminkan tingkat kepercayaan investor dalam menanmkam modalnya, sehingga akan meningkatkan nilai perusahaan. Investor beranggapan perusahaan yang memliki hutang besar, maka kemampuan mendapatkan lapa omptimal akan besar pula. Dengan modal yang kuat perusahaan dapat melakukan inovasi produk dan invansi pasar untuk dapat meperoleh konsumen sebanyakbanyaknya. Modal perusahaan dapat dipenuhi dari dua sisi yaitu ekuiatas dan modal pinjaman. Ekuitas dapat diperoleh lewat pasar modal. Pemilihan sumber dana perusahaan akan berpengaruh pada laba per lembar saham yang pada akhirnya akan berpengaruh pada nilai perusahaan. Semakin efektif perusahaan menggunakan sumber dana dari pinjaaman, maka meningkatkan laba perusahaan per lembar saham atau nilai perusahaan semakin meningkat. Tetapi dibalik itu sumber dana pinjaman memliki resiko tinggi yaitu beban bunga pada perusahaan. Sedangkan alternatif lain perusahaan menggunakan sumber dana dari ekuitasnya.

\section{Pengaruh Kepemilikan Manajerial Terhadap Nilai perusahaan}

Dari hasil analisis yang telah dilakukan dapat diketahui bahwa variabel kepemilikan manajerial berpengaruh positif terhadap nilai perusahaan Pertambangan yang terdaftar di Bursa Efek Indonesia Periode 2014-2018. Hal ini menunjukkan bahwa semakin tinggi kemepilikan saham manajemen yang dimilikinya, maka keptusan-keputusan manajerial akan mengarah pada ksejehateraan pemegang saham, sehingga mampu meningkatkan nilai perusahaan.

Hal ini senada dengan penelitian yang dilakukan oleh Miraza dan Muniruddin (2017), yang menyatakan bahwa kepemilkikan manajerila berpenagruh positif terhadap Nilai perusahaan. Pengaruh kepemilikan manajerial terhadap nilai perusahaan bersifat positif artinya, setiap kenaikkan kepemilikan manajerial, maka akan diikuti kenaikkan Nilai perusahaan. Hal ini sesuai pendapat Kasmir (2016) yng menyatakan bahwa struktur kepemilikian saham manajerial akan berdampak pada bagaimana manajemen melakukan investasi sesuai harapan pemilik perusahaan. Komposisi saham manajerial dengan jumlah saham beredar disebut struktur kepemilikan manajerial. Saham yang dikuasai manajer dibandingkan dengan seluruh saham beredar adalah kepemilikan manajerial. Semakin besar kepemilikan manajerial, maka manajemen akan berusaha secara optimal dalam meningkatkan nilai perusahaan. Hal ini karena dengan komposisi kepemilikan saham yang lebih besar maka manajemen memiliki kepentingan harapan return saham yang besar, untuk itu faktor keterlibatan manajemen dalam kepemilikan saham akan berpengaruh pada perkembangan perusahaan secara menyeluruh, termasuk nilai perusahaan. 


\section{KESIMPULAN}

Perencanaan pajak tidak berpengaruh terhadap nilai Perusahaan Pertambangan yang terdaftar di Bursa Efek Indonesia Periode 2014-2018. Debt to Equity Ratio (DER) berpengaruh positif terhadap nilai perusahaan Pertambangan yang terdaftar di Bursa Efek Indonesia Periode 20142018. Kepemilikan manajerial

\section{SARAN-SARAN}

Bagi perusahaan supaya dapat meningkatkan nilai perusahaan perlu memperhatikan perencanaan pajak dan struktur modal yang diukur dengan DER. Hasil penelitian dapat digunakan sebagai bahan penyediaan informasi keuangan yang lengkap dan jelas untuk mengurangi informasi asimetri dan sebagai sumber

\section{REFERENSI}

Ardilasari, R. (2013). Pengaruh Return on Equity (ROE), Price Earnings Ratio (PER), Nilai perusahaan (EPS ), Rasio Utang dan Debt to Equity Ratio (DER) Terhadap Harga Saham Pada Perusahaan Food and Beverage yang Terdaftar di Bursa Efek Indonesia Periode 2008-2010. Skripsi. Universitas Muhammadiyah Surakarta: Surakarta.

Brigham, Eugene F dan Houston, Joel F. (2014). Dasar-Dasar Manajemen Keuangan. Edisi 11. Jakarta : Salemba Empat.

Darsono, Ashari. (2015). Pedoman Praktis Memahami Laporan Keuangan. Yogyakarta: ANDI.

Ghozali, Imam. (2011). Aplikasi Analisis Multivariate Dengan Program SPSS. Semarang : Badan Penerbit Universitas Diponegoro.

Gitosudarmo, Indrio. (2002). Manajemen Keuangan, Edisi 4. Yogyakarta: BPFE.

Hanlon, Michelle dan Shane Heitzman. 2013. A Review of Tax Research. berpengaruh positif terhadap nilai Perusahaan Pertambangan yang terdaftar di Bursa Efek Indonesia Periode 20142018. Perencanaan Pajak, Debt to Equity Ratio (DER), dan kepemilikan Manajerial secara simultan berpengaruh positif dan signifikan terhadap Nilai perusahaan.

informasi mengenai kondisi Nilai perusahaan oleh pihak eksternal.

Bagi penelitian selanjutnya. pemilihan sampel penelitian sebaiknya jumlah sampel lebih diperbanyak lagi agar tercipta distribusi data yang lebih baik. Bagi peneliti selanjutnya, sebaiknya menambah variabel bebas yang lain yang sekiranya mampu mempengaruhi Nilai perusahaan.

Journal of Accounting and Economics, (50), pp:127 - 178.

Kasmir. (2016). Analisis Laporan Keuangan. Jakarta: PT.Raja Grafindo Persada

Kieso, Donald E., Jerry J. Weygandt, dan Terry D. Warfield, 2012. Akuntansi Intermediete, Terjemahan Emil Salim, Jilid 1, Edisi Kesepuluh, Penerbit Erlangga, Jakarta.

Libby, R. (2014). Akuntansi Keuangan. (Ahli bahasa: J. Agung Saputro). Yogyakarta : ANDI.

Lubis Ade Fatima, (2011), Pasar Modal, (Jakarta: Lembaga Penerbit FE UI.

Munawir, S. (2012). Analisa Laporan Keuangan, Yogyakarta, Penerbit Liberty.

Pradnyana Ida Bagus Gede Putra dan Noviari Naniek (2017), "Pengaruh Perencanaan Pajak Terhadap Nilai Perusahaan Dengan Transparansi Perusahaan Sebagai Variabel Moderasi”. E-Jurnal Akuntansi Universitas Udayana Vol.18.2. 
Sartono, Agus R., 2016. Manajemen Keuangan Teori dan Aplikasi. Yogyakarta.

Sawir, Agnes. (2015). Analisis kinerja keuangan dan perencanaan keuangan perusahaan. PT Gramedia pustaka utama. Jakarta.

Suandy, Erly. (2014). Perencanaan Pajak. Jakarta: Salemba Empat.

Sugiyono. (2016). Metodologi Penelitian. Jakarta : Alfa Beta.

Sunariyah, (2013). Pengantar Pengetahuan Pasar Modal, edisi ke tiga, UPP-AMP YKPN, Yogyakarta.

Tandelilin Aduardus,. (2015). Fortofolio dan Investasi. Yogyakarta : Konisius

Wild, John, K.R. Subramanyam, dan Robert F. Halsey. (2017). Analisis Laporan Keuangan. Edisi Delapan, Buku Kesatu. Alih Bahasa : Yanivi dan Nurwahyu. Jakarta: Salemba Empat

Wulandari, May dan Dovi Septiari. (2016).

Effective Tax Rate: Efek dari

Corporate Governance.

Jurnal.polibatam.ac.id 